\title{
Adaptive designs: current status, future outlook
}

Andy Grieve

From Clinical Trials Methodology Conference 2011

Bristol, UK. 4-5 October 2011

The world of pharmaceutical statistics has taken adaptive designs to its heart - at least in theory. However despite the very large number of methodological publications and presentations at conferences there are still very few examples of adaptive designs in the medical literature. In this talk I will discuss why this might be the case and will suggest areas where these approaches are likely to be of greatest value in the future.

Published: 13 December 2011

Submit your next manuscript to BioMed Central and take full advantage of:

- Convenient online submission

- Thorough peer review

- No space constraints or color figure charges

- Immediate publication on acceptance

- Inclusion in PubMed, CAS, Scopus and Google Scholar

- Research which is freely available for redistribution

\section{Biomed Central}

